\title{
Efek Tayangan Demonstrasi Sebagai Stimulus Untuk Pengaruhi Aktivitas Denyut Jantung Sebagai Representasi Reaksi Kemarahan
}

\author{
Erik Saut H Hutahaean ${ }^{1}$, Yuarini Wahyu Pertiwi ${ }^{1}$, Hema Dayita Pohan ${ }^{1}$, Tiara Anggita \\ Perdini ${ }^{1{ }^{*},}$, Ryan Bastoro ${ }^{1}$ \\ ${ }_{1}^{1}$ Fakultas Psikologi; Universitas Bhayangkara Jakarta Raya; Jl. Perjuangan 081, Marga \\ Mulya, Bekasi Utara; 02188955882/ +622188955871; e-mail: erik.saut@dsn.ubharajaya.ac.id, \\ yuarini.wp@dsn.ubharajaya.ac.id, hema.dayita@dsn.ubharajaya.ac.id, \\ tiaraanggitaperdini@gmail.com, bastoro.ryan@gmail.com \\ * Korespondensi: e-mail: tiaraanggitaperdini@gmail.com
}

Submitted: 19/04/2021; Revised: 26/04/2021; Accepted: 10/05/2021; Published: 27/05/2021

\begin{abstract}
Heart rate is an indicator to see mental activity in humans. Anger is a mental activity that has been investigated in many previous studies. There have been uses of impressions as a stimulus, but not yet in 360 format (virtual reality). This study is a preliminary study to determine the impact of demonstration impressions on heart rate activity. Impressions are made in two forms; Riot demonstrations and peaceful demonstrations, which were given to the subjects using the Virtual Reality Box. A total of 40 subjects were involved to reject their heartbeats and were given the intervention of broadcast 1 for riot demonstration and broadcast 2 for peace. Heart rate is measured through the blood flow read by a sensor bracelet, to further differentiate heart rate differences that occur in subjects. The results of the observation analysis found that there was a difference in the subject's heart rate when given 1 and 2 impressions. The results of comparative trials have proven that demonstration impressions can have an impact on different heart rates when compared to peaceful demonstrations.
\end{abstract}

Keywords: Anger, Demonstrations, Heart Rate, Impressions

\begin{abstract}
Abstrak
Denyut jantung menjadi indikator untuk melihat aktivitas mental pada manusia. Kemarahan merupakan aktivitas mental yang banyak dipelajari pada penelitian yang sebelumnya. Penggunaan tayangan sebagai stimulus sudah pernah ada yang melakukannya, tetapi format tayangannya belum dalam format 360 (virtual realitiy). Studi ini merupakan kajian awal untuk menggali dampak tayangan demontrasi terhadap aktivitas denyut jantung. Tayangan dibuat dalam dua bentuk; demontrasi rusuh dan demontrasi damai, yang diberikan kepada subjek dengan menggunakan Virtual Reality Box. Sebanyak 40 subjek dilibatkan untuk diukur denyut jantungnya dan diberikan intervensi tayangan 1 untuk demontrasi rusuh serta tayangan 2 untuk demonstrasi damai. Denyut jantung diukur melalui aliran darah yang terbaca oleh sensor wristband, untuk selanjutnya diperiksa perbedaan-perbedaan heart rate yang terjadi pada subjek. Hasil analisis pengamatan mendapatkan adanya perbedaan heart rate pada subjek saat diberikan tayangan 1 dan diberikan tayangan 2. Hasil hitung uji perbandingan berhasil membuktikan bahwa tayangan demontrasi rusuh dapat berdampak kepada heart rate secara berbeda ketika dibandingkan dengan demontrasi yang damai.
\end{abstract}

Kata kunci: Kemarahan, Demontrasi, Heart Rate, Tayangan 


\section{Pendahuluan}

Demonstrasi menjadi salah satu dinamika sosial yang terus berdampak terhadap kehidupan (Lambert et al., 2010), dampaknya dapat berwujud rusaknya sarana dan fasilitas publik. Menurut Winarno (2019), demonstrasi merupakan wujud kebebasan masyarakat dalam memberikan pendapat serta kebebasan berekspresi. Demonstrasi merupakan penyaluran aspirasi yang mungkin terhambat oleh penguasa atau individu-individu lain. Demonstrasi ada yang dilakukan dengan provokasi-provokasi yang bertubi-tubi (Sergeevna, 2014), dan ada juga instigasi yang membuat demontrasi menjadi suatu bentrokan yang massif (Agbor, 2013). Wujud provokasi yang dapat dilihat dalam aktivitas demonstrasi yaitu seperti adanya celaan atau hinaan, memberikan informasi palsu, serta menunjukan emosi yang berlebihan (Sergeevna, 2014). Instigasi ditandai dengan terjadinya serangan balasan (Mandel, 2002), sedangkan provokasi merupakan hasutan yang diberikan demonstran untuk memancing kemarahan (Poerwadarminta, 2003). Emosi-emosi yang dirasakan individu, seperti rasa marah yang timbul akibat provokasi dapat diungkap melalui aktivitas denyut jantung (heart rate) dan respon perilaku kemarahan (Denson, Grisham, \& Moulds, 2011).

Denyut jantung diketahui dengan mengenali terlebih dahulu siklus jantung (Morais et al., 2019). Peristiwa yang terjadi pada jantung hingga muncul denyut jantung pertama, dan selanjutnya maka disebut sebagai siklus jantung, kemudian membentuk siklusnya. Adapun bentuk siklus jantung adalah sistolik dan diastolic (Mcconnell \& Hull, 2020). Bentuk diastolic merupakan representasi dari periode relaksasi jantung, sedangkan bentuk sistolik merupakan periode pengisian yang diikuti dengan periode knatraksi (Rhoades \& Bell, 2019). Curah jantung ditandai dengan adanya proses pemompaan darah, jantung memompa darah ke dalam aorta dalam setiap menitnya (Saugel, Heeschen, Hapfelmeier, Romagnoli, \& Greiwe, 2020). Maka banyaknya darah yang mengalir melalui sirkulasi disebut sebagai curah jantung. Darah dialirkan keseluruh jaringan tubuh, yang sebanding dengan luasnya permukaan tubuh. Curah jantung dapat memperlihatkan adanya penurunan saat manusia berada pada fase usaia lanjut (Foppa et al., 2016). Laki-laki dan perempuan memiliki curah jantung yang berbeda (Finke et al., 2018), hal itu dapat diketahui saat istirahat yang besaranya adalah $5.6 \mathrm{~L} /$ menit untuk laki-laki, dan untuk perempuan curah jantungnya adalah $4.9 \mathrm{~L} /$ menit.

Studi-studi tentang heart rate ada yang difokuskan kepada variasi heart rate yang terjadi dalam satu kurun waktu pengamatan, dan ada juga yang melihatnya melalui rerata denyut jantung yang terjadi pada subjek dalam satu kurun waktu pengamatan (Francis, Penglis, \& McDonald, 2016;Abdillah et al., 2020). Ada yang diperhatikan melalui grafik pergerakan denyut jantung melalui aliran darah (Marther \& Thayer, 2019) dan ada juga yang milihatnya melalui pendekatan medis (Wilson et al., 2016). Pusat kendali aktivitas jantung dilakukan oleh pusat vasometer, hal ini terjadi secara bersamaan ketika mengatur derajat konstriksi vaskuler, dan pada waktu yang bersamaan juga mengendalikan jantung (Guyton \& Hall, 2016). Karena menjadi pengendali, maka pusat vasomotor juga dapat meningkatkan dan menurunkan aktivitas jantung (Nalivaiko, Davis, Blackmore, Vakulin, \& Nesbitt, 2015), dapat diketahui melalui 
kontraksi jantung (vasokonstriksi), dan pengahambatan kontraksi (vasodilatasi). Perubahan cepat pada aktivitas detak jantung juga tidak terlepas dari kinerja saraf parasimpatus (Thayer, Åhs, Fredrikson, Sollers, \& Wager, 2012). Saat seseorang marah denyut jantungnya berdetak bertambah lebih cepat, dibandingkan dengan saat dalam keadaan normal (Lupis, Lerman, \& Wolf, 2014). Pada penelitian ini akan dibuatkan Kondisi buatan mengenai demonstrasi, melalui kondisi dalam laboratorium yang dibuat untuk melihat dampak-dampak psikologis yang terjadi pada orang-orang yang menyaksikan demontrasi. Kondisi buatannya dengan memberikan tayangan, dan mengamati dampak psikologis yang direpresentasikan melalui reaksi fisiologis dari mental, berupa denyut jantung.

Penelitian sebelumnya telah berhasil mengungkap denyut jantung dan respon-respon kemarahan, yang diungkapkan melalui tayangan-tayangan yang memuat unsur-unsur emosi, dalam hal ini yang dapat memberikan pengaruh terhadap heart rate. Pertama merupakan penelitian yang dilakukan oleh Mohamed, Jusoh, \& Ahmad (2013), Hasil studi menunjukan adanya perbedaan detak jantung permenit (bpm), pada subjek yang keadaan emosinya normal rata-rata detak jantungnya $<90$ bpm, sedangkan yang emosionalnya marah detak jantung $>90$. Denyut jantung yang diperhatikan pada studi tentang kemarahan diperoleh melalui frekuensinya yang dihitung dalam satuan beat per-minute (bpm), seperti studi yang dilakukan oleh Mohamed, Jusoh, \& Ahmad (2013) yaitu tentang perbedaan denyut jantung dalam ukuran bpm. Studi yang lainnya berhasil mengungkap kaitan antara denyut jantung dengan agresi reaktif yang tinggi dan juga agresi proaktif (Xu, Raine, Yu, \& Krieg, 2014). Penelitian sebelumnya sudah ada yang membahas mengenai dampak tayangan kekerasan terhadap kemarahan yang dipantau melalui aktivitas detak jantung. Penelitian pertama yaitu dari Huesmann, Moise-Titus, Podolski, \& Eron (2003), penelitiannya membahas mengenai studi longitudinal dimana anak-anak diberikan tayangan kekerasan hingga usia dewasa awal, tayangan tersebut didapatkan melalui acara televise yang menggambarkan sikap kekerasan. Hasilnya menyatakan bahwa tayangan kekerasan dapat meningkatkan agresifitas pada laki-laki maupun perempuan. Kedua merupakan penelitian yang dilakukan oleh Lawrence \& Hodgkins (2009), dalam penelitiannya Lawrence dan Hodgkins juga mengkaitkan unsur tayangan. Tayangan yang digunakan merupakan 3 rekaman kamera CCTV. Selanjutnya Troop-Gordon, Gordon, Vogel-Ciernia, Ewing Lee, \& Visconti (2018), dalam penelitiannya ia menggunakan tayangan dari subjeknya sendiri. Dimana sebelum melihat tayangan tersebut, subjeknya diminta untuk memperagakan beberapa adegan kekerasan dan kemudian direkam.

Berbeda dari penelitian terdahulu yang menggunakan tayangan dari CCTV atau acara televise, penelitian ini akan menggunakan video 360 sebagai media tayangan. Kemajuan teknonologi tentang video grafis saat ini sudah pada fase penggunaan video 360 , yang dapat dinikmati dengan lebih nyaman dengan menggunakan Virtual Reality Box. Canggihnya teknologi video saat dapat membuat tayangan-tayangan dalam format biasa dapat dirubah menjadi format 360 , dan bisa disaksikan dengan kotak VR. Penelitian ini berusaha untuk menyusun suatu studi untuk melihat dampak dari tayangan dalam format 360 terhadap aktivitas 
denyut jantung. Virtual reality merupakan gambar video yang dimunculkan dalam bentuk 3 dimensi, yang dapat terlihat seperti nyata dengan bantuan peralatan tertentu (Gea \& Maulany, 2020). Melalui virtual reality ini, individu yang menontonnya dapat merasakan sensasi nyata seperti berada secara langsung dengan tempat kejadian didalam video tersebut. Dengan sensasi tersebut dapat memungkinkan data responden menjadi lebih jujur apa adanya. Penelitian ini akan menggunakan instrument tayangan video virtual reality untuk melihat pengaruh tayangan demonstrasi terhadap reaksi kemarahan responden yang dipantau melalui aktivitas detak jantung.

\section{Metode Penelitian}

Penelitian ini menggunakan teknik eksperimen laboratorium, yaitu dengan menggabungkan serta mengembangkan beberapa alat yang telah ada dan mengujinya langsung kepada para subjek penelitian. Penelitian ini juga menggunakan pengamatan yang objektif yang dibuat dalam kondisi terkontrol secara ketat. Data yang diambil merupakan data hasil lapangan. Data empiris merupakan suatu fakta yang secara langsung dapat diamati serta diukur sehingga setiap pertanyaan penelitian dapat dibuktikan (Pratisti \& Yuwono, 2018). Adapun proses atau tahapan-tahapan yang dipersiapkan sebelumnya yaitu:

\subsection{Menentukan Tayangan}

Tayangan ditentukan berdasarkan konsep demonstrasi yang dapat memancing kemarahan. Pada fase ini tayangan masih dalam format biasa. Selanjutnya didapatkan dua tayangan yang akan dijadikan sebagai stimulus penelitian. Tayangan yang dipilih adalah tayangan demonstrasi rusuh dan tayangan demontrasi damai. Bahan tayangan diperoleh peneliti melalui media sosial yang menyediakan akses gratis untuk dapat disaksikan dan diunduh.

\subsection{Membandingkan Tayangan}

Tayangan berikutnya akan diistilahkan dengan T1 (demonstrasi rusuh) dengan durasi 9 menit 5 detik dan T2 (demonstrasi damai) dengan durasi 5 menit. 4 detik. Selanjutnya kepada 46 subjek diberikan kuesioner mengenai tayangan yang disaksikannya, dan diminta untuk memberikan penilaian apakah ada unsus kekerasan yang dapat memancing kemarahan saat subjek menyaksikannya. T1, dan juga terhadap T2. Hasil penilaian awal memperlihatkan nilai yang berbeda dengan perbandingan nilai rerata 4.9 berbanding 1.3 antara T1 dan T2.

Tabel 1. Karakteristik Tayangan

\begin{tabular}{cc}
\hline Karakteristik T1 & Karakteristik T2 \\
Rusuh & Damai \\
\hline Adegan Simbol atau Tulisan kasar & Ada orator di tengah demonstran \\
\hline Adegan pengerusakan property polisi & Adegan tanpa pengrusakan property \\
\hline Adegan penyerangan kepada aparat & Menyampaikan tuntutan merdeka \\
\hline Adegan kerumunan saling mendorong & Tertib, masa banyak, media spanduk dan atribut \\
\hline Sumber: Hasil Penelitian (2021) &
\end{tabular}




\subsection{Menyusun Tayangan Dengan Format 360}

T1 dan T2 selanjutnya dibuat dan disusun dengan format tayangan video 360 , yang akan diberikan dengan menggunakan kotak VR. Prosesnya adalah dengan menggunakan salah satu media sosial yang menyediakan fasilitas untuk dapat membuat tayangan biasa dapat disaksikan dengan format 360. Karena menggunakan kotak VR, maka proses pemberian tayangan dengan menggunakan smartphone1 yang tampilannya sudah terhubung dengan perangkat laptop. Adapun perangkat laptop menjadi media bagi peneliti untuk dapat mengobservasi jalannya tayangan.

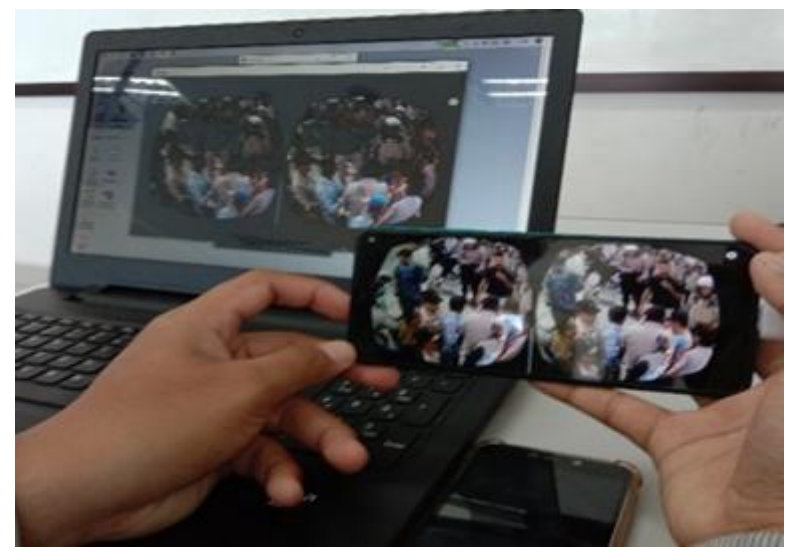

Sumber: Hasil Penelitian (2021)

Gambar 1. Tampilan Tayangan 360

\subsection{Menyusun Konsep Pengamatan Denyut Jantung}

Data denyut jantung yang dibutuhkan dalam penelitian adalah denyut jantung berdasarkan aliran darah, yang diamati menggunakan sensor wristband (Huawei band5), sehingga data yang dapat dilihat adalah data denyut dalam satuan bpm (bit per menit). Wristband dihubungkan dengan aplikasi yang terdapat pada smartphone2, tentunya yang kompatibel dengan wristband. Denyut jantung yang terlihat pada smartphne2 terhubung dengan laptop, sehingga data denyut jantung yang terlihat pada smartphone2 juga terlihat pada laptop.

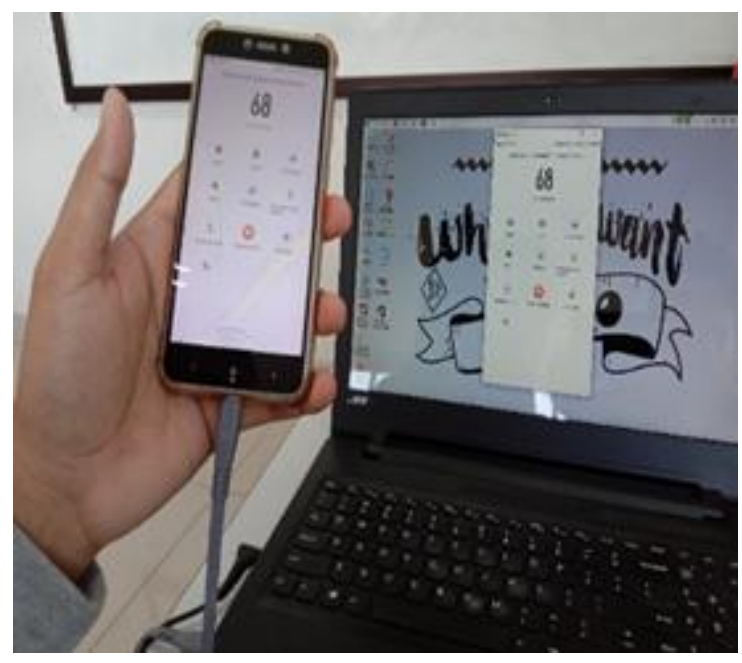

Sumber: Hasil Penelitian (2021)

Gambar 2. Pengamatan Denyut Jantung Melalui Alat 


\subsection{Pengambilan Data}

Alat dapat digunakan dalam keadaan tampilan pada kedua telepon seluler juga tampil pada layar computer portable, dan juga suara tayangan dapat keluar dengan jelas pada headset yang melekat di kacamata VR. Ada catatan penting yang harus diperhatikan saat memasangkan pemutar pada kaca mata VR, yaitu poisi gambar harus tepat. Karena tayangan diputar dalam format video 360 (virtual reality).

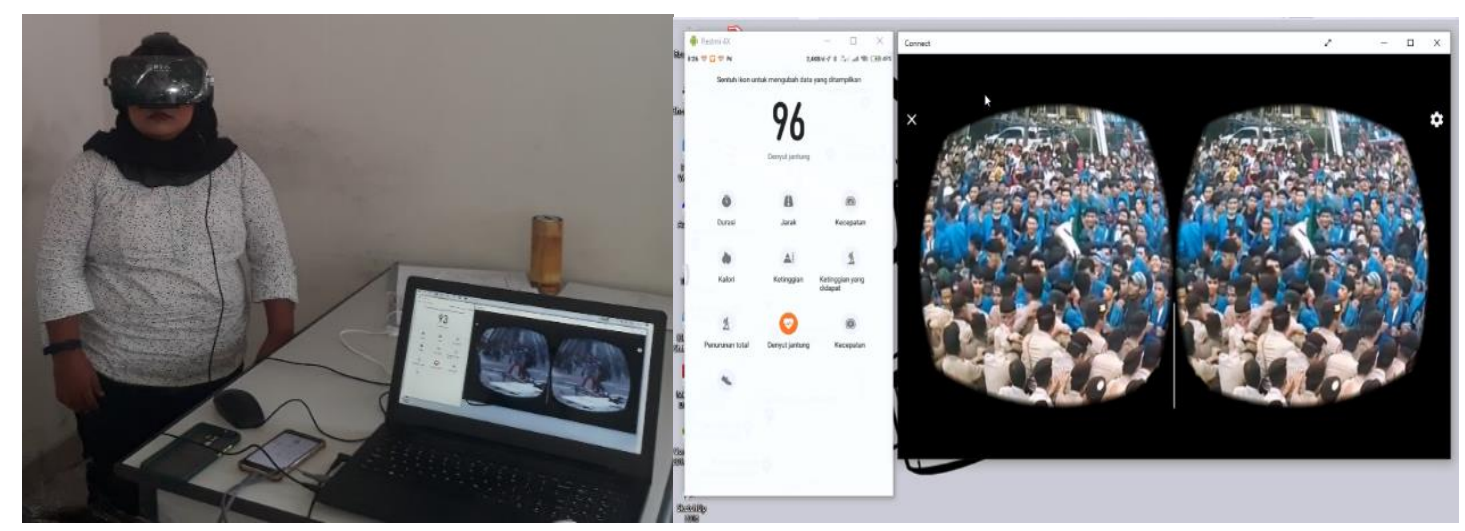

Sumber: Hasil Penelitian (2021)

\section{Gambar 3. Tampilan Saat Uji Coba Alat}

Proses pengambilan data dilakukan pada ruang tertutup yang hening atau dengan peredam yang cukup. Selama proses subjek melakukannya dengan posisi berdiri agar dapat mendalami video (diatur sesuai kenyamanan subjek). Agar proses pemberian tayangan dapat berjalan lancar, diperlukan ketersediaan jaringan paket data yang terhubung dengan baik dan kondisi sinyal stabil. Mengingat tayangan hanya dapat diputar dengan menggunakan jaringan berbasis internet. T1 diberikan pada subjek yang sama. Selama proses penghambilan data, tampilan denyut jantung dan videonya direkam dan disimpan untuk keperluan olah data penelitian. Data yang diamati adalah denyut jantung yang terjadi selama pemberian stimulus. Setelah sesi pemberian tayangan selesai, kepada subjek diberikan kuesioner untuk menilai tayangan yang disaksikannya. Data dari kuesioner tersebut akan digunakan untuk melihat peneliaian subjek terhadap T1 dan T2 dengan format 360 .

\subsection{Uji Data}

Data denyut jantung yang diamati adalah pergerakan setiap denyut (aktivitas) selama subjek menyaksikan tayangan. Total pergerakannya dihitung, kemudian dibandingkan antara pergerakan denyut efek T1 dan pergerakan denyut efek dari T2. Studi ini juga menganalisis rerata denyut jantung selama subjek menyaksikan tayangan, untuk kemudian nilai rerata denyut efek T1 dibandingkan dengan nilai rerata T2. Sebagaimana yang dijelaskan tentang cara menentukan tayangan. Teknik statistic untuk menguji data tersebut menggunakan uji komparasi paired sampel, karena memperhatikan pengukuran denyut T1 dan pengukuran denyut T2. 


\section{Hasil dan Pembahasan}

\subsection{Pergerakan Denyut Pada T1 dan T2}

Sebagai penjelasan pengantar bahwa durasi untuk T1 adalah 9 menit 5 detik (9.5) dan durasi T2 5 menit 4 detik (5.4), untuk meminimalkan pengaruh durasi terhadap perbedaan pergerakan denyut, maka yang dihitung adalah pergerakan dibagi dengan jumlah durasi. Pergerakan atau aktivitas denyut jantung merupakan setiap perubahan angka denyut jantung selama menyaksikan tayangan. Untuk meminimalkan terjadinya aktivitas jantung karena ada gerakan otot. Selama menyaksikan tayangan subjek diminta berdiri dalam ruang lingkup terbatas.

Tabel 2. Paired Sample T-test

\begin{tabular}{|c|c|c|c|c|c|c|c|c|}
\hline Measure 1 & $\begin{array}{l}\text { Measure } \\
2\end{array}$ & Test & Statistic & df & p & $\begin{array}{l}\text { Location } \\
\text { Parameter }\end{array}$ & $\begin{array}{c}\text { SE } \\
\text { Difference }\end{array}$ & $\begin{array}{c}\text { Effect } \\
\text { Size }\end{array}$ \\
\hline \multirow[t]{2}{*}{$\begin{array}{l}\text { AJ T2 } \\
\text { dibagi } \\
\text { durasi }\end{array}$} & $\begin{array}{ll}\text { AJ } & \text { T1 } \\
\text { dibagi } & \\
\text { durasi } & \\
\end{array}$ & Student & 27.544 & 39 & $<.001$ & 8.148 & 0.296 & 4.355 \\
\hline & & Wilcoxon & 820.000 & & $<.001$ & 8.208 & & 1.000 \\
\hline \multirow[t]{2}{*}{ HR Ave T2 } & $\begin{array}{l}\text { HR } \quad \text { Ave } \\
\text { T1 }\end{array}$ & Student & 2.766 & 39 & 0.009 & 1.828 & 0.661 & 0.437 \\
\hline & & Wilcoxon & 630.000 & & 0.003 & 1.803 & & 0.537 \\
\hline \multirow[t]{2}{*}{$\begin{array}{l}\text { Penilaian } \\
\text { T1 }\end{array}$} & $\begin{array}{l}\text { Penilaian } \\
\text { T2 }\end{array}$ & Student & 16.240 & 39 & $<.001$ & 3.375 & 0.208 & 2.568 \\
\hline & & Wilcoxon & 780.000 & & $<.001$ & 3.500 & & 1.000 \\
\hline
\end{tabular}

Sumber: Hasil Penelitian (2021)

Hasil pengamatan memperlihatkan bahwa dari 40 subjek yang dilibatkan berhasil diketahui rata-rata pergerakan jantung 10,518 dampak dari T1, dan juga diketahui rata-rata dampak T2 adalah sebanyak 18,306 pergerakan jantung. Aktivitas jantung yang terjadi selama menyaksikan T1 menunjukan ada perbedaan dibandingkan dengan aktivitas jantung yang terjadi selama menyaksikan T2. Hasil pengkuran denyut jantung memperlihatkan rerata aktivitas jantung dengan selisih yang signifikan. Hasil hitung tersebut dapat dikuatkan karena ada efek ukuran sebesar 4.355, hal ini merepresentasikan adanya efek ukuran yang kuat meskipun subjek penelitian yang dilibatkan tergolong sedikit.

\subsection{Rata-rata denyut pada $\mathrm{T} 1$ dan $\mathrm{T} 2$}

Denyut jantung yang diamati adalah berupa angka denyut dengan ukuran denyut per menit (bpm). Hasil hitung rata-rata denyut dampak T1 dibandingkan dengan hasil hiutng ratarata denyut dampak T2, dan mendapatkan angka bahwa terdapat perbedaan rata-rata besarnya denyut jantung yang muncul akibat T1 dibandingkan dengan akibat T2. rata-rata denyut jentung akibat T1 lebih kecil dari rata-rata denyut jantung akibat T2 (98,856bpm < $100,685 \mathrm{bpm})$. Hasil ini memperlihatkan adanya variansi yang berbalik, meskipun terdapat selisih nilai rerata dampak T1 dan T2 terhadap denyut jantung.

Rata-rata besarnya denyut jantung permenit dampak dari $\mathrm{T} 1$ memperlihatkan perbedaan yang signifikan dibandingkan dengan rata-rata besarnya denyut jantung dampak dari T2. Hasil tersebut merepresentasikan bahwa dampak T1 terhadap besarnya denyut jantung lebih kecil dibandingkan dengan dampak dari T2. 
Tabel 3. Descriptive

\begin{tabular}{lcccc}
\hline & $\mathrm{N}$ & Mean & $\mathrm{SD}$ & $\mathrm{SE}$ \\
\hline AJ T2 dibagi durasi & 40 & 18.306 & 1.773 & 0.280 \\
\hline AJ T1 dibagi durasi & 40 & 10.158 & 0.552 & 0.087 \\
\hline HR Ave T2 & 40 & 100.685 & 10.989 & 1.737 \\
\hline HR Ave T1 & 40 & 98.856 & 9.577 & 1.514 \\
\hline Penilaian T1 & 40 & 5.325 & 0.997 & 0.158 \\
\hline Penilaian T2 & 40 & 1.950 & 0.959 & 0.152 \\
\hline
\end{tabular}

Sumber: Hasil Penelitian (2021)

\subsection{Terdapat perbedaan penilaian subjek mengenai $\mathrm{T} 1$ dan $\mathrm{T} 2$}

Setelah menyaksikan tayangan subjek diberikan kuesioner untuk menilai T1 dan T2, analisa dilakukan dengan subjek yang sama dengan subjek yang menyaksikan tayangan. Pertanyaan fokus kepada unsur kekerasan yang dapat memancing kemarahan yang terjadi di dalam tayangan. Hasilnya memperlihatkan adanya perbedaan penilaian subjek tentang $\mathrm{T} 1$ dan T2. Hasil ini juga memperlihatkan konsistensi penilaian T1 dan T2 sebelum tayangan dirubah dalam format 360, karena menunjukan adanya perbedaan penilaian terhadap T1 dan T2. Subjek pada penilaian awal dan penilaian akhir didapatkan dari subjek yang berbeda

Tabel 4. Paired Sample T-test

\begin{tabular}{|c|c|c|c|c|c|c|}
\hline Measure 1 & Measure 2 & Test & Statistic & df & p & $\begin{array}{l}\text { Effect } \\
\text { Size }\end{array}$ \\
\hline $\begin{array}{l}\text { Penilaian } \\
\text { Awal T2 }\end{array}$ & $\begin{array}{l}\text { Penilaian } \\
\text { Awal T1 }\end{array}$ & Student & 7.663 & 45 & $<.001$ & 1.130 \\
\hline & & Wilcoxon & 741.000 & & $<.001$ & 0.900 \\
\hline $\begin{array}{c}\text { Penilaian } \\
\text { Kembali T2 }\end{array}$ & $\begin{array}{l}\text { Penilaian } \\
\text { Kembali } \\
\text { T1 }\end{array}$ & Student & 5.302 & 39 & $<.001$ & 0.838 \\
\hline & & Wilcoxon & 552.000 & & $<.001$ & 0.752 \\
\hline
\end{tabular}

Sumber: Hasil Penelitian (2021)

Hasilnya memperlihatkan bahwa penilaian terhadap T2 dianggap lebih besar untuk memungkinkan subjek dapat terpancing untuk marah. Meskipun T1 memuat banyak tindakan kekerasan, namun dianggap oleh subjek tidak memberikan kemungkinan yang sama besarnya dengan T2. Hasil uji ini merepresentasikan bahwa T2 dianggap sebagai stimulus yang lebih besar peluangnya untuk dapat memberikan dampak kemarahan, dibandingkan dengan dampak dari T1.

\subsection{Pembahasan}

Pergerakan jantung dapat diamati melalui setiap perubahan denyut jantung dalam kurun waktu tertentu (Acharya, Joseph, Kannathal, Lim, \& Suri, 2006). Waktu untuk T1 adalah 9.5 dan untuk T2 adalah 5.4, secara durasi memang terlihat berbeda. Tetapi durasi tersebut dijadikan sebagai pembagi untuk menghitung pergerakan denyut jantung. Pergerakan denyut jantung terjadi lebih banyak pada T2 $(\mathrm{T} 1<\mathrm{T} 2)$. Merujuk kepada teori, pergerakan denyut jantung 
sangat ditentukan oleh gerakan-gerakan otot tubuh (Gladwell \& Coote, 2002), dan juga aktivitas mental yang melanda sistem emosi (Appelhans \& Luecken, 2006). Pergerakan akan terjadi sejalan dengan terjadinya perubahan-perubahan aliran darah. Hasil yang diperoleh dalam penelitian memberikan gambaran mengenai fakta bahwa pergerakan denyut jantung lebih besar disebabkan oleh tayangan demontrasi yang berisi ucapan tuntutan dari demonstran, walaupun demo berjalan dengan tertib dan damai. T2 merupakan tayangan yang hanya memuat tentang kejadian tindak kekerasan yang dilakukan pada saat-saat demonstrasi, dan tidak ada pengucapan tuntutan dari demonstran, berisi adegan-adegan pengerusakan dan penyerangan.

Denyut jantung pada orang yang mengalami reaksi emosi marah rata-rata berada pada kisaran $>90 \mathrm{bpm}$. Pada saat individu mengalami perasaan marah, maka pergerakan denyut jantung akan terus meningkat (Wati, Puspitasari, Muarifah, Yudhana, \& Dahlan, 2019). Sebuah hasil penelitian berhasil mengungkap mengenai subjek yang mengalami reaksi emosi marah denyut jantungnya >90 bpm (Mohamed et al., 2013). Perhatikan data rerata besarnya denyut jantung pada data deskriptif. Terlihat bahwa T1 dan T2 memiliki nilai rerata $>90 \mathrm{bpm}$, artinya merujuk kepada hasil bahwa kondisi subjek saat menyaksikan tayangan berada dalam kondisi emosi yang marah. Tetapi perlu memperhatikan lebih lanjut, karena rata-rata bpm $\mathrm{T} 1<$ ratarata bpm T2. Seperti ada interpretasi yang berlawanan antara penilaian subjek dengan denyut jantung yang dialaminya. Artinya efek tayangan terhadap denyut jantung memberikan dampak yang berlawanan, karena denyut tayangan demontrasi yang tidak rusuh lebih dapat membangkitkan kemarahan. Fakta ini menandakan bahwa keadaan emosi marah lebih disebabkan karena kata-kata yang terucap saat demonstrasi (meskipun berjalan secara tertib dan damai) dibandingkan hanya sekedar menyaksikan suatu keadaan demonstrasi yang rusuh (Andersen, Carnagey, \& Eubanks, 2003).

Tayangan yang memuat kekerasan tidak dapat menjadi stimulus pemancing kemarahan, sebaliknya justru tayangan demonstrasi yang memuat adanya orasi mengenai suatu tuntutan dianggap lebih mungkin untuk dijadikan sebagai stimulus pemancing kemarahan. Adegan-adegan pengerusakan property, penyeerangan secara langsung belum cukup kuat untuk dapat memancing kemarahan, jika dibandingkan dengan tayangan demonstrasi damai yang di dalamnya ada orasi mengenai suatu tuntutan, dan juga tuntutan melalui poster-poster, serta atribut-atribut lainnya.

\section{Kesimpulan}

Penelitian ini telah mendapatkan hasil bahwa tayangan aksi demonstrasi dalam bentuk video 360 berhasil mempengaruhi aktivitas heart rate. Tayangan aksi ricuh dan tayangan aksi damai sama-sama memicu emosi kemarahan pada subjek, namun tayangan yang paling memicu rasa kemarahan adalah tayangan aksi damai. Hal ini disebabkan karena aksi damai lebih menekankan pada perkataan-perkataan dan penjelasan dalam aksinya, hal ini ternyata lebih menimbulkan rasa kemarahan dari pada tayangan aksi ricuh yang menekankan aksi 
kekerasan dan perusakan property publik. Penelitian ini masih memiliki keterbatasan dalam mengkonfirmasi kondisi mengenai kemarahan melalui kuesioner atau alat ukur lainnya. Seperti misalnya kemarahan yang perlu dikonfirmasi melalui konsep anger provocation. Oleh karena itu penelitian selanjutnya dapat mengarahkan konsep tentang film atau tayangan didasarkan kepada teori-teori provokasi yang kemudian dapat berdampak kepada munculnya respon dan keadaan internal terkait kemarahan.

\section{Daftar Pustaka}

Abdillah, R., Pertiwi, Y. W., Hutahaean, E. S. H., Bastoro, R., Putri, R. A. P., \& Perdini, T. A. (2020). Self-monitoring dan Kemampuan Verbal Terhadap Perilaku Berbohong. Jurnal Kajian IImiah, 20(3), 249-260. https://doi.org/10.31599/jki.v20i3.283

Acharya, U. R., Joseph, K. P., Kannathal, N., Lim, C. M., \& Suri, J. S. (2006). Heart rate variability: A review. Medical and Biological Engineering and Computing, 44(12), 10311051. https://doi.org/10.1007/s11517-006-0119-0

Agbor, A. A. (2013). Instigation to Crimes against Humanity: The Flawed Jurisprudence of the International Criminal Tribunal for Rwanda (ICTR). Boston: Martinus Nijhoff Publisher.

Andersen, C. A., Carnagey, N. L., \& Eubanks, J. (2003). Exposure to Violent Media: The Effects of Songs with Violent Lyrics on Aggressive Thoughts and Feelings. Journal of Personality and Social Psychology, 84(5), 960-971. https://doi.org/10.1037/0022-3514.84.5.960

Appelhans, B. M., \& Luecken, L. J. (2006). Heart rate variability as an index of regulated emotional responding. Review of General Psychology, 10(3), 229-240. https://doi.org/10.1037/1089-2680.10.3.229

Denson, T. F., Grisham, J. R., \& Moulds, M. L. (2011). Cognitive reappraisal increases heart rate variability in response to an anger provocation. Motivation and Emotion, 35(1), 14-22. https://doi.org/10.1007/s11031-011-9201-5

Finke, S. R., Schroeder, D. C., Ecker, H., Wingen, S., Hinkelbein, J., Wetsch, W. A., ... Böttiger, B. W. (2018). Gender aspects in cardiopulmonary resuscitation by schoolchildren: A $\begin{array}{llll}\text { systematic review. } & \text { Resuscitation, }\end{array}$ https://doi.org/10.1016/j.resuscitation.2018.01.025

Foppa, M., Arora, G., Gona, P., Ashrafi, A., Salton, C. J., Yeon, S. B., ... Chuang, M. L. (2016). Right Ventricular Volumes and Systolic Function by Cardiac Magnetic Resonance and the Impact of Sex, Age, and Obesity in a Longitudinally Followed Cohort Free of Pulmonary and Cardiovascular Disease: The Framingham Heart Study. Circulation: Cardiovascular Imaging, 9(3), 1-8. https://doi.org/10.1161/CIRCIMAGING.115.003810

Francis, H. M., Penglis, K. M., \& McDonald, S. (2016). Manipulation of heart rate variability can modify response to anger-inducing stimuli. Social Neuroscience, 11(5), 545-552. https://doi.org/10.1080/17470919.2015.1115777

Gea, S., \& Maulany, R. (2020). Perancangan Aplikasi Virtual Reality 360 Berbasis Web di Universitas Advent Indonesia. TelKa, 10(2), 135-142. 
https://doi.org/10.36342/teika.v10i2.2383

Gladwell, V. F., \& Coote, J. H. (2002). Heart rate at the onset of muscle contraction and during passive muscle stretch in humans: A role for mechanoreceptors. Journal of Physiology, 540(3), 1095-1102. https://doi.org/10.1113/jphysiol.2001.013486

Guyton, A. ., \& Hall, J. E. (2016). BUKU AJAR Fisiologi Kedokteran (KE-12; M. . Widjajakusumah \& A. Tanzil, eds.). Elsevier Singapore Pte Ltd.

Huesmann, R. R., Moise-Titus, J., Podolski, C. L., \& Eron, L. D. (2003). Longitudinal Relations between Children's Exposure to TV Violence and Their Aggressive and Violent Behavior in Young Adulthood: 1977-1992. Developmental Psychology, 39(2), 201-221. https://doi.org/10.1037/0012-1649.39.2.201

Lambert, A. J., Scherer, L. D., Schott, J. P., Olson, K. R., Andrews, R. K., O’Brien, T. C., \& Zisser, A. R. (2010). Rally Effects, Threat, and Attitude Change: An Integrative Approach to Understanding the Role of Emotion. Journal of Personality and Social Psychology, 98(6), 886-903. https://doi.org/10.1037/a0019086

Lawrence, C., \& Hodgkins, E. (2009). Personality influences on interpretations of aggressive behavior: The role of provocation sensitivity and trait aggression. Personality and Individual Differences, 46(3), 319-324. https://doi.org/10.1016/j.paid.2008.10.022

Lupis, S. B., Lerman, M., \& Wolf, J. M. (2014). Anger responses to psychosocial stress predict heart rate and cortisol stress responses in men but not women. Bone, 23(1), 1-7. https://doi.org/10.1016/j.psyneuen.2014.07.004.Anger

Mandel, D. R. (2002). Evil and the Instigation of Collective Violence. Analyses of Social Issues and Public Policy, 2(1), 101-108. https://doi.org/10.1111/j.1530-2415.2002.00030.x

Marther, M., \& Thayer, J. (2019). How heart rate variability affects emotion regulation brain $\begin{array}{llll}\text { networks. Physiology \& Behavior, } & 176(3), & 139-148 .\end{array}$ https://doi.org/10.1016/j.cobeha.2017.12.017.How

Mcconnell, T. H., \& Hull, K. L. (2020). Human Form, Human Function: Essentials of Anatomy \& Physiology, Enhanced Edition. Jones \& Bartlett Learning.

Mohamed, M., Jusoh, N. ., \& Ahmad, I. . (2013). Anger Mood Detection Based On Face Recognition And Heartbeat. International Journal of Engineering Research \& Technology (IJERT), 2(2).

Morais, M. J. D., Raimundo, R. D., Oliveira, F. S., De Abreu, L. C., Bezerra, I. M. P., Silva, R. P. M., ... Pérez-Riera, A. R. (2019). Evaluation of the effects of aerobic training during hemodialysis on autonomic heart rate modulation in patients with chronic renal disease. Medicine (United States), 98(23), 1-7. https://doi.org/10.1097/MD.0000000000015976

Nalivaiko, E., Davis, S. L., Blackmore, K. L., Vakulin, A., \& Nesbitt, K. V. (2015). Cybersickness provoked by head-mounted display affects cutaneous vascular tone, heart rate and reaction time. Physiology and Behavior, 151(November), 583-590. https://doi.org/10.1016/j.physbeh.2015.08.043

Poerwadarminta, W. J. . (2003). Kamus Umum Bahasa Indonesia. Jakarta: Balai Pustaka. 
Pratisti, W. D., \& Yuwono, S. (2018). Psikologi Eksperimen (Konsep, Teori, dan Aplikasi). Surakarta: Muhammadiyah University Press.

Rhoades, R., \& Bell, D. R. (2019). Medical Physiology: Principles for Clinical Medicine (3rd ed.). Philadephia: Lippincott Williams \& Wilkins.

Saugel, B., Heeschen, J., Hapfelmeier, A., Romagnoli, S., \& Greiwe, G. (2020). Cardiac output estimation using multi-beat analysis of the radial arterial blood pressure waveform: a method comparison study in patients having off-pump coronary artery bypass surgery using intermittent pulmonary artery thermodilution as the reference me. Journal of Clinical Monitoring and Computing, 34(4), 649-654. https://doi.org/10.1007/s10877-019-00375-z

Sergeevna, V. O. (2014). Communicative Provocation As a Strategy of Destructive Behavior in Every-Day Conflict. 5(24), 49-56.

Thayer, J. F., Åhs, F., Fredrikson, M., Sollers, J. J., \& Wager, T. D. (2012). A meta-analysis of heart rate variability and neuroimaging studies: Implications for heart rate variability as a marker of stress and health. Neuroscience and Biobehavioral Reviews, 36(2), 747-756. https://doi.org/10.1016/j.neubiorev.2011.11.009

Troop-Gordon, W., Gordon, R. D., Vogel-Ciernia, L., Ewing Lee, E., \& Visconti, K. J. (2018). Visual Attention to Dynamic Scenes of Ambiguous Provocation and Children's Aggressive Behavior. Journal of Clinical Child and Adolescent Psychology, 47(6), 925-940. https://doi.org/10.1080/15374416.2016.1138412

Wati, D. E., Puspitasari, I., Muarifah, A., Yudhana, A., \& Dahlan, U. A. (2019). Recognizing Parents Emotions through Heart Beat Sensors as Prevention Efforts Parents Violence toward Children. Proceedings: International Conference on Early Childhood Development (ICECD), 35-39.

Wilson, S. T., Chesin, M., Fertuck, E., Keilp, J., Brodsky, B., Mann, J. J., ... Stanley, B. (2016). Heart rate variability and suicidal behavior. Psychiatry Research, 240(May 2017), 241247. https://doi.org/10.1016/j.psychres.2016.04.033

Winarno, S. (2019, September 25). Demokrasi, Demonstrasi, dan Demo Crazy. Arsip Publikasi IImiah Biro Administrasi Akademik.

Xu, Y., Raine, A., Yu, L., \& Krieg, A. (2014). Resting heart rate, vagal tone, and reactive and proactive aggression in Chinese children. Journal of Abnormal Child Psychology, 42(3), 501-514. https://doi.org/10.1007/s10802-013-9792-2 